\title{
Floristic, Structural, and Conservation Analysis of the Habitats Occupied by Dupont's Lark, Chersophilus duponti, in the Northwest Edge of Its Distributional Range
}

\author{
Juan Luis Aguirre, Carlos Talabante, Alejandro Aparicio, Manuel Peinado \\ Cátedra de Medio Ambiente, Departamento de Ciencias de la Vida, Universidad de Alcalá, Madrid, Spain \\ Email: juanl.aguirre@uah.es
}

Received 25 May 2016; accepted 7 August 2016; published 10 August 2016

Copyright (C) 2016 by authors and Scientific Research Publishing Inc.

This work is licensed under the Creative Commons Attribution International License (CC BY). http://creativecommons.org/licenses/by/4.0/

(c) (i) Open Access

\begin{abstract}
This paper describes and analyzes floristic, structural and conservation features of the shrubland occupied by Chersophilus duponti in the northwest corner of its world distribution range. This study relates the coverage, floristic composition with estimated lark density in the area. We identified four types of shrublands, three of them varied significantly in floristic composition for the habitats of this species in contrast with those of their world distribution: Cistus ladanifer scrubs; heaths dominated by Ericaceae, and scrubs dominated by the genera Lavandula, Thymus and Cytisus. The fourth type, dominated by aromatic chamaephytes and grass, fits descriptions of the bird's typical habitat. The areas sampled are subject to different categories of threats, the most significant being the natural succession process due to the cessation of grazing, reforestation measures and the use of flat areas for farmlands or other uses. The density of larks in this area was directly related to coverage-composition of plant community.
\end{abstract}

\section{Keywords}

Alaudidae, Passerine Birds, Vegetation-Birds Relationships, Steppe Birds, Conservation Status

\section{Introduction}

Among the steppe birds with current population decline are several members of the family Alaudidae [1]. Although the reasons for their demise are varied, the majority of larks are highly sensitive to modifications to their habitats [2]. When designing management measures to protect decreasing bird or other populations, a good knowledge of the habitat requirements of each species is essential. 
Larks have been the victims of niche separation caused by ever changing dryland agricultural practices [3]. This has meant that many conservation strategies pursue the preservation of crop edges, which offer both food and protection for birds [2] [4]. However, not all species depend on these sites for nesting and seek out more natural spaces during the breeding season [3]. This also means a need for detailed knowledge of the preferred habitats of each species throughout its life cycle.

One of the species of the family Alaudidae that is most sensitive to perturbations of its habitat is the Dupont's lark Chersophilus duponti. This passerine bird is among the rarest in the western Paleartic and is today only found in the Iberian Peninsula and North Africa [5] [6]. The species is also among the least well known throughout Europe and many issues related to its behavior, conservation state and habitat selection are still largely unclear [7].

Several reports have described the distribution of Dupont's lark in Spain, and most of these have provided numbers of individuals and population distributions [6] [8] [9]. However, few studies have focused on its habitat selection [10] [11] or dispersion patterns [6].

The largest populations of Dupont's lark are found in the Iberian High Plateaus, or "parameras" [7] (Picture 1), whose plant communities are exposed to extreme weather conditions typical of the Supramediterranean parameras, including severe winds, prolonged snowfall, low rainfall and intense sunlight, among other adverse factors [12]. Populations may also be locally common in the open shrublands of Mesomediterranean brackish depressions of the Ebro basin and very much scarcer in the coastal thermo-Mediterranean scrubs of the southeastern Iberian Peninsula ([7] [10] [11] and personal data).

Despite numerous literature references to the species' habitat, no solid and documented conclusions have been generated in order to relation the abundance of this bird with its preferences of habitats in terms of floristic composition [13]. In the Iberian Peninsula, the species is generally associated with non-dense, more or less open shrubland found on plains with slopes gentler than $15 \%$ [14]. These sites occur as steppe-like patches of natural vegetation spread across vast expanses of dryland crops and wastelands. The present study describes from a floristic, structural and conservation perspective scrubs inhabited by Dupont's lark in the northwestern limits of its world distribution area. Besides living among plant communities of very different structure and floristic composition from those of their habitats across the rest of their distribution range, populations are found relatively far from others, suggesting a worsening process of population isolation [15] [16].

\section{Material and Methods}

The study area was the northwestern quadrant of Spain spanning the provinces of Zamora and Palencia (Spain). Sampling sites were selected based on the 2007 census perfomed by Suárez and Garza as well as data provided in the census in Zamora 2008 [17]. In the Zamora province, the species occupies the western portion, while in Palencia it appears exclusively in the region of El Cerrato (Figure 1). In both provinces, Dupont's lark appears

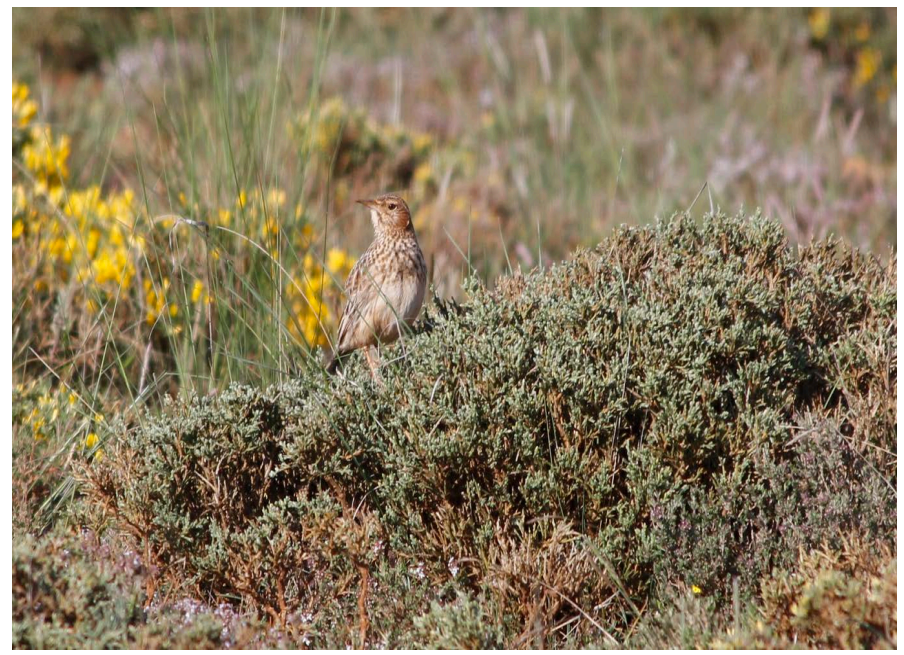

Picture 1. Dupont's lark, Chersophilus duponti, in the typical habitat in Iberian High Plateaus, or "parameras” (Guadalajara, Spain). 


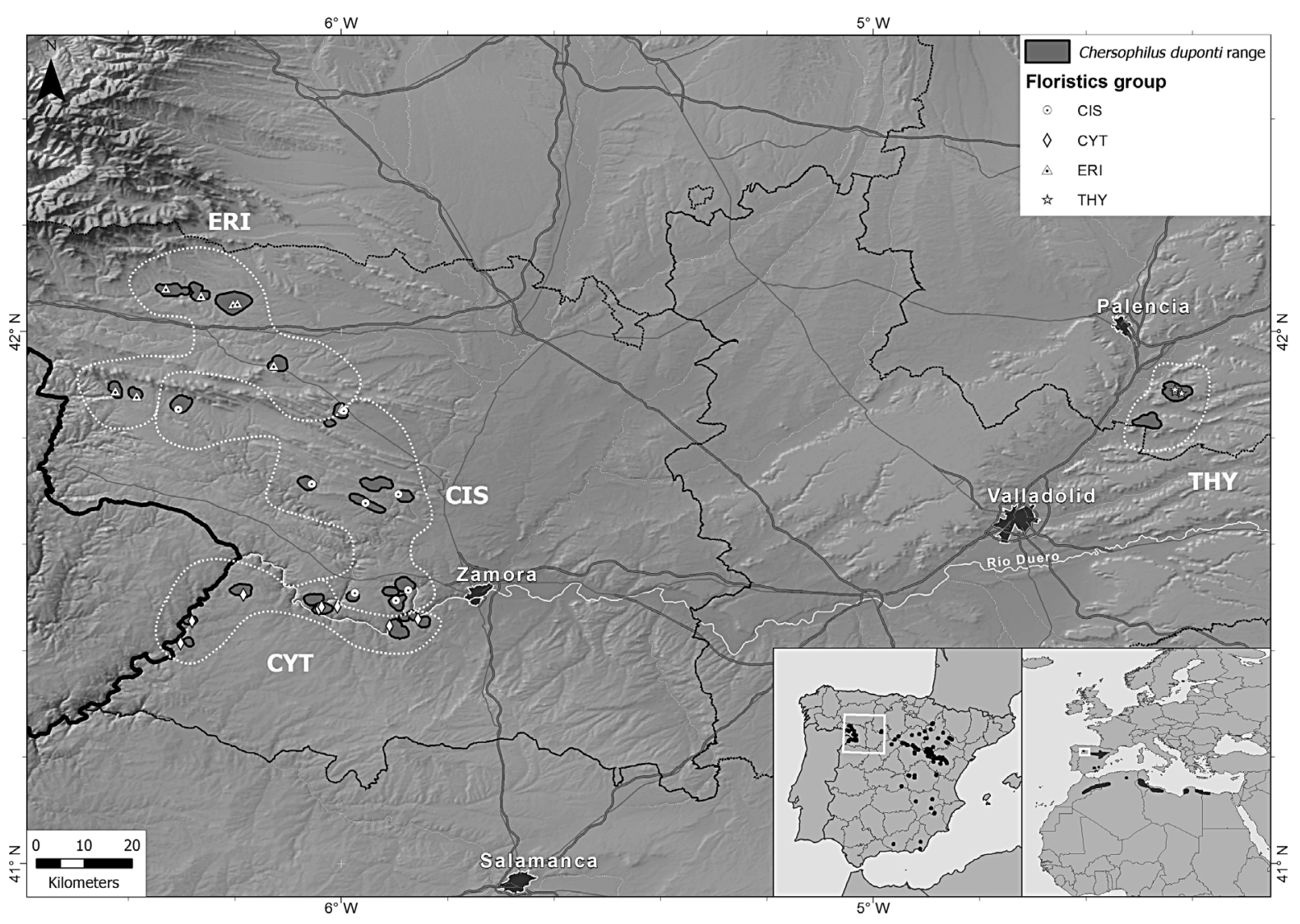

Figure 1. Relevés taken in the provinces of Zamora and Palencia (Spain) according to the known distribution of Chersophilus duponti in this zone. Black solid line is Portugal-Spain border. CIS; ERI, CYT, THY-PA are group of different types of vegetation (see text).

in landscapes typical of the Northern Meseta consisting of Supramediterranean scrublands scattered among extensive farmlands, woods and reforested pine forests.

A set of 29 relevés or sampling plots were taken and analyzed according to Braun-Blanquet methods [18] both in zones where the species currently exists according to the most recent census, and in those where it is considered recently extinguished [6]. Edaphic and geologic data were previously obtained from bibliographic and cartographic sources. Elevation (msl), aspect, slope, stoniness (\%) and parent rock material were recorded. Relevé plots at each site were selected according to homogeneity of physical features, vegetation structure and species dominance. Plot size was based on the concept of the minimum area of relatively uniform stands [19]. Cover was estimated for perennial vascular plants according to the ordinal scale of Braun-Blanquet (1979) as modified by [20] r (rare species), + (cover < 1\%), 1 (cover 1 to 20\%), 2a (cover 20 to 30\%), 2b (cover 30 to 40\%), 3 (cover 40 to 60\%), 4 (cover 60 to $80 \%$ ) and 5 (cover 80 to 100\%).

A total of 81 vascular taxa was recorded. Using several regional floras, plants were identified as far as possible in the field and specimens of dubious identification collected for subsequent laboratory determination. Plant nomenclature usually follows Flora Ibérica [21] and phytosociological nomenclature follows Peinado [22]. Plant associations and alliances were identified by comparison with studies of the area and number of habitat were identified with the Interpetation Manual of European Union Habitats (2013) and [23] [24].

For the numerical analysis, Braun-Blanquet cover values were ordinally transformed: + was replaced by 1, 1 by 2, 2 (a, b) by 4,3 by 6, 4 by 7 and 5 by 8 . Analyses were performed using SPSS v22.0 software (IBM, Somers, NY, US) starting with a data set (29 relevés) that included each plant recorded in the relevés (81), along with its respective transformed cover value.

Numerical classification of the relevés was based on squared Euclidean distances calculated by an Average Linkage Clustering method of similarity (ALC). This is one of the most frequently used methods in vegetation 
similarity analysis, in which the process of fusion is based on the minimum average distance between individuals and groups. The benefits of ALC over single or complete linkage clustering have been summarized by reference.

In order to relate estimated lark density and floristic composition, a dimensionality reduction with floristic and cover data of releves on the basis of principal component analysis (PCA) was perfomed. This summarizes the complexity of floristic data. Density is calculated with data of potential habitat and estimated territories in each location with 2009 census. After with principal components and estimated density we performed a multiple linear regressión. This method is used in some studies with these types of data [25]-[27] with robust results.

\section{Results}

The cluster diagram obtained from the relevés (Figure 2) delimits four groups. Statistical data and the floristic set in each group are provided in Table 1.

Group ERI includes silicicolous heaths co-dominated by Erica species: Erica aragonensis, E. scoparia, E. umbellata, Genistella tridentata and Halimium ocymoides, whose relevés were recorded in the northernmost part of the world distribution range of Dupont's lark.

Group CIS gathers scrubs dominated by Cistus ladanifer, whose typical companion species are Lavandula pedunculata and Quercus rotundifolia sprouts. These scrubs correspond to Upper Mesomediterranean and silicicolous "jarales" ("jara” is the Spanish name for Cistus species), which are typically dense and show scarce floristic diversity.

Group CYT comprises acid bushlands ("piornales") dominated by brooms (Leguminosae scrub, nano- and micro-phanerophytes with long flexible, slender green stems and branches, mainly of the genera Genista and Cytisus), with Lavandula pedunculata and Thymus mastichina as the most frequent companions.

Group THY-PA consists of basophilous low scrubs flourishing in El Cerrato (Palencia). Of the four groups, these scrubs show the greatest floristic diversity. Most common species were Helianthemum hirtum, Helichrysum stoechas, Thymus zygis, Genista scorpius and grasses such as Festuca hystrix or Stipa iberica.

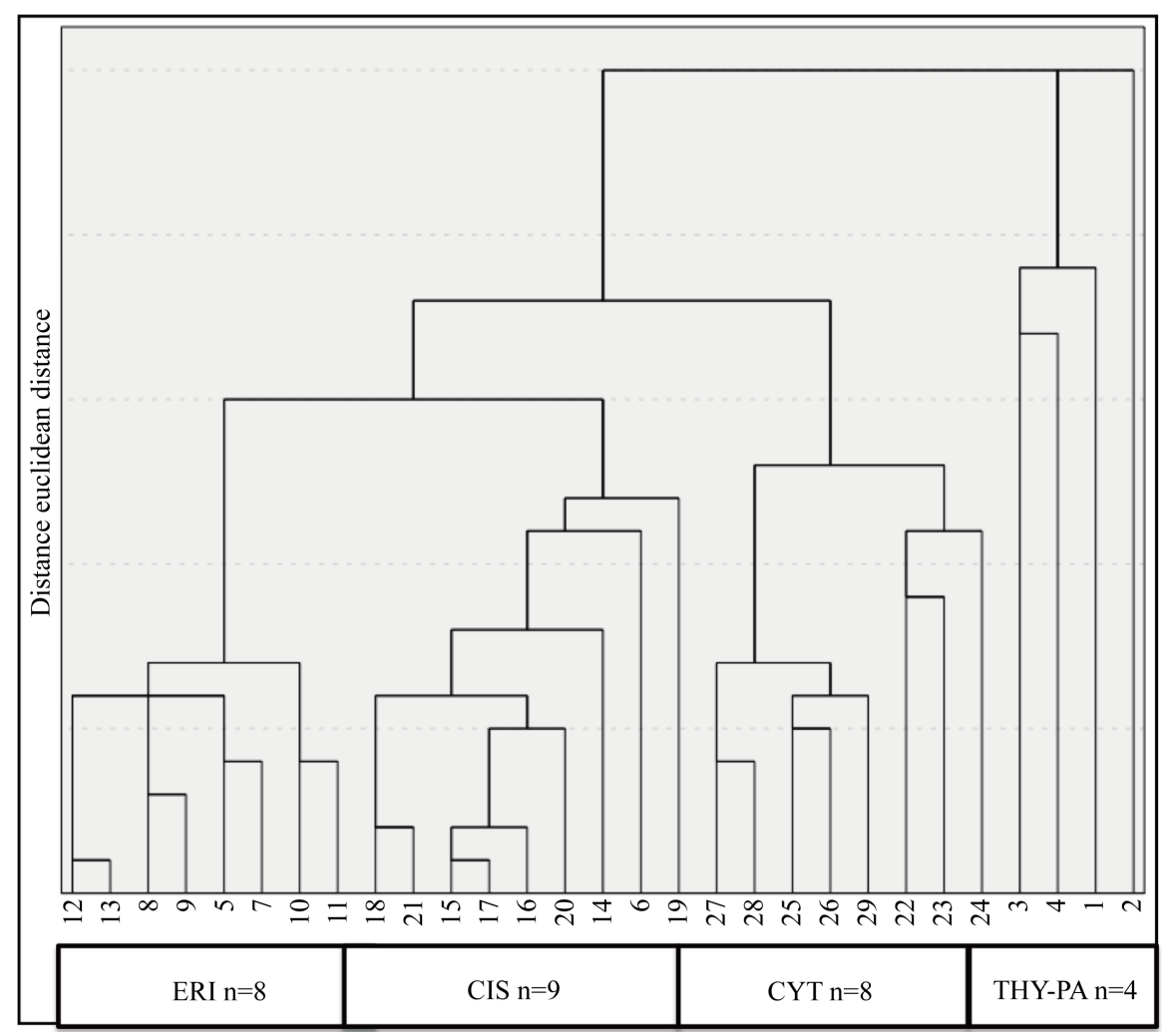

Figure 2. Cluster dendrogram of the 29 relevés taken in the study area. To details see text. 
Table 1. Frequency and cover percentages recorded in the relevé groups. Only most representative plant species (appearing at frequency $\geq 33 \%$ ) and interesting bioindicators are included.

\begin{tabular}{|c|c|c|c|c|c|c|c|c|}
\hline Vegetation group & ERI & & CIS & & CYT & & THY-PA & \\
\hline Altitude (meters) & 855 & & 769 & & 744 & & 728 & \\
\hline Cover vegetation (\%) & 79 & & 72 & & 49 & & 69 & \\
\hline Height vegetation (\%) & 47 & & 80 & & 49 & & 25 & \\
\hline \multirow[t]{2}{*}{ Estimated density (Territories/ha) } & 0.05 & & 0.06 & & 0.13 & & 0.02 & \\
\hline & Fre $\%$ & Cover \% & Fre $\%$ & Cover \% & Fre \% & Cover \% & Fre \% & Cover \% \\
\hline Erica umbellata & 100 & 38 & & & & & & \\
\hline Hallimium ocymoides & 100 & 26 & 13 & 1 & & & & \\
\hline Genista tridentata & 67 & 8 & & & 25 & 1 & & \\
\hline Erica aragonensis & 67 & 14 & 13 & 1 & & & & \\
\hline Halimium lasianthum ssp alyssoides & 56 & 12 & 13 & 1 & & & & \\
\hline Calluna vulgaris & 44 & 4 & & & & & & \\
\hline Erica scoparia & 44 & 9 & & & & & & \\
\hline Halimium umbellatum ssp viscosum & 33 & 3 & 13 & 1 & 13 & 9 & & \\
\hline Adenocarpus complicatus & 22 & 1 & 25 & 3 & & & & \\
\hline Cistus ladanifer & 22 & 7 & 88 & 66 & 25 & 1 & & \\
\hline Genista florida ssp polygaliphylla & & & 38 & 3 & & & & \\
\hline Agrostis castellana & & & 38 & 11 & & & & \\
\hline Lavandula pedunculata & 22 & 7 & 75 & 12 & 100 & 35 & & \\
\hline Cytisus scoparius & & & & & 100 & 23 & & \\
\hline Thymus mastichina & & & 25 & 2 & 100 & 22 & 100 & 10 \\
\hline Quercus rotundifolia & 11 & 1 & 38 & 3 & 75 & 5 & 50 & 5 \\
\hline Daphne gnidium & & & 13 & 1 & 63 & 4 & & \\
\hline Dactylis hispanica & & & & & 63 & 4 & & \\
\hline Santolina rosmarinifolia & & & & & 50 & 3 & & \\
\hline Helianthemum cinereum & & & & & 50 & 4 & & \\
\hline Astragalus sp. & & & & & 50 & 3 & & \\
\hline Armeria duriaei & & & & & 38 & 5 & & \\
\hline Genista hystrix & & & 13 & 3 & 38 & 5 & & \\
\hline Thymus zygis & & & & & 38 & 8 & & \\
\hline Genista falcata & 11 & 1 & & & 25 & 1 & & \\
\hline Cytisus multiflorus & & & & & 13 & 3 & & \\
\hline Quercus pyrenaica & 11 & 1 & 13 & 1 & & & & \\
\hline Pinus pinaster & 11 & 1 & & & & & & \\
\hline Helichrysum stoechas & & & & & & & 100 & 10 \\
\hline Helianthemum hirtum & & & & & 25 & 1 & 100 & 13 \\
\hline Genista scorpius & & & & & & & 75 & 6 \\
\hline Eringyum campestre & & & & & 50 & 3 & 75 & 6 \\
\hline Stipa iberica & & & & & & & 75 & 18 \\
\hline Dorycnium pentaphyllum & & & & & & & 75 & 6 \\
\hline Hieracium sp. & & & & & & & 75 & 6 \\
\hline Salvia lavandulifolia & & & & & & & 75 & 6 \\
\hline Thymus zygis & & & & & & & 50 & 11 \\
\hline Helianthemum oelandicum & & & & & & & 50 & 4 \\
\hline Achillea odorata & & & & & & & 50 & 5 \\
\hline Coris monspeliensis & & & & & & & 50 & 5 \\
\hline Knautia arvensis & & & & & & & 50 & 5 \\
\hline Leuzea conifera & & & & & & & 50 & 5 \\
\hline Phlomis lychnitis & & & & & & & 50 & 5 \\
\hline Rosa micrantha & & & & & & & 50 & 5 \\
\hline Lavandula latifolia & & & & & & & 50 & 9 \\
\hline Festuca hystrix & & & & & 38 & 3 & 50 & 13 \\
\hline Thymus vulgaris & & & & & & & 25 & 6 \\
\hline
\end{tabular}


With data of cover and floristic presence we performed a PCA. The results showed that the four first of principal components explain the $67.91 \%$ of the floristic and coverage variance in the 29 releves (Figure 3).

After, we calculated estimated density in all locations, with data of 2009 census and habitat potencial estimation [6]. We obtained that density of larks in the area are from 0.02 territories by hectare to 0.25 territories by hectare, with CYT group much more dense that the rest of groups.

We did not find a direct relation between density and vegetation cover clases, altitude, total cover of species neither stoniess area. We performed a multiple regressión and ANOVA analysis between data of density by relevés (standardized) and the three first PCA components. We obtained that there is a very significance relation between components obtained from floristic composition and coverage, and the density of larks in the relevés (Figure 3, Table 2).

\section{Discussion}

With the exception of the low scrubs of El Cerrato (THY-PA), the shrublands examined in our study had little in common in florist terms with those described throughout the known distribution range of Dupont's lark (Picture 1) $[6]$.

The El Cerrato (group THY-PA) scrubs, in calcic soils, show a similar structure to that observed in the Iberian System, Spain ([6]; and personal observations). These very open scrubs, usually appear as isolated patches of native habitat with dwarf woody plants (average vegetation height $c .25 \mathrm{~cm}$ ) belonging to the Supramediterranean alliance Siderito incanae-Salvion lavandulifoliae (Table 3). Their communities usually constitute secondary communities arising from the destruction of the natural potential vegetation of juniper woodlands (Juniperetum hemisphaerico-thuriferae, habitat type 856111) or mixed evergreen forests (Junipero thuriferaeQuercetum rotundifoliae, 834033) due to fires, grazing or agricultural use and subsequent erosion of the upper soil layer [23].

Because these isolated scrubland patches of El Cerrato occur between those of Zamora and the Iberian System, a main Dupont's lark population center, they could play an important role in increasing the connectivity of Dupont's lark. In effect, references [14] [28] provided evidence that in fragmented, degraded, landscapes such "stepping stones" increased connectivity and population sizes.

However, of the two areas occupied by Dupont's lark in El Cerrato (Palencia), one was recently extinguished and the other was very disturbed with scarce patches of natural vegetation and subjected to disparate land uses such as farming, landfills, quarries, etc. If this trend of anthropogenic degradation continues, the survival of these last populations in this area is unlikely. This area, which could be an important link between the populations of

Table 2. Multiple regressión, model summary, and ANOVA analysis between data of lark’s density by relevés (standardized) and the three first PCA components.

\begin{tabular}{|c|c|c|c|c|c|}
\hline Model & B & Standard error & Beta & $\mathrm{t}$ & Sig. \\
\hline K & -31.199 & 7.443 & & -4.192 & 0 \\
\hline comp1 & 71.979 & 13.796 & 1.174 & 5.217 & 0 \\
\hline comp2 & 13.598 & 2.672 & 0.67 & 5.089 & 0 \\
\hline comp3 & 30.016 & 5.317 & 1.25 & 5.645 & 0 \\
\hline Model & $\mathrm{R}$ & \multicolumn{2}{|c|}{$\mathrm{R} 2$} & R2 adjusted & Sig. F \\
\hline \multirow[t]{2}{*}{1} & $0.825 a$ & \multicolumn{2}{|c|}{0.68} & 0.634 & 0 \\
\hline & Sum of squares & df & Mean quadratic & $\mathrm{F}$ & Sig. \\
\hline Regresión & 1.722 .542 & 3 & 574.181 & 14.87 & 0.00 \\
\hline Rests & 810.891 & 21 & 38.614 & & \\
\hline Total & 2.533 .434 & 24 & & & \\
\hline
\end{tabular}

a. Dependent variable: Density100ha Variables: (K), comp1, comp2, comp3. 

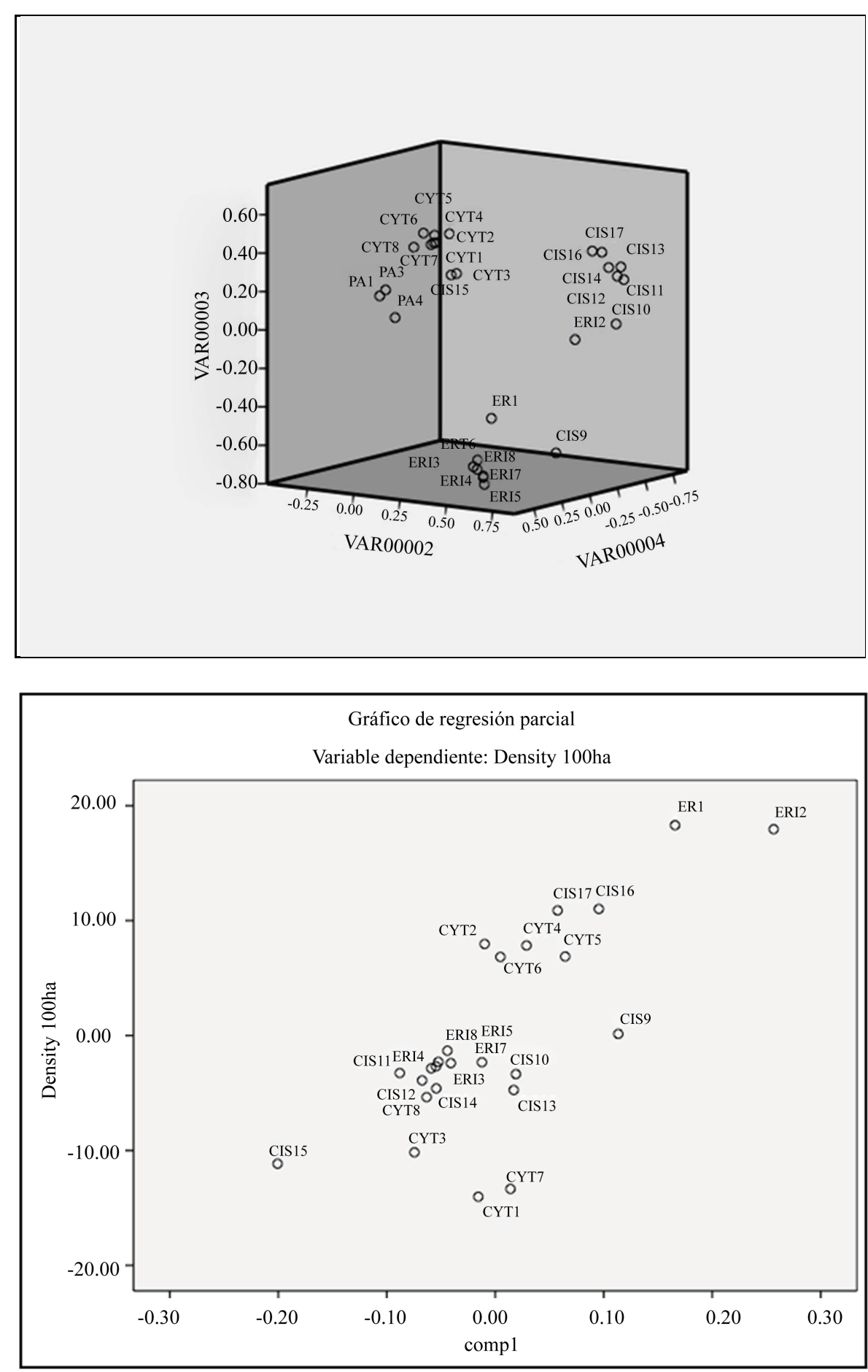

Figure 3. Above: PCA analysis of relevés, showing the 3 first factors. ERI, CYT, CIT and THY- PA show the group of the relevés (read text). Down: relation between transformed density and first component of PCA.

western and eastern areas, but it is in a very bad condition (Picture 2, Figure 1).

The heathlands (group ERI), shrubs of Cistus ladanifer (group CIS) and piornales (CYT) of northwest area differ widely from those described as typical of the species. All are acid soil vegetation communities, a real peculiarity worldwide for Dupont's lark. Heathlands (ERI) of the phytosociological class Calluno-Ulicetea are 
Table 3. Summary with assotiation and bioclimatic features of habitat occupied by Dupont's lark in the study area.

\begin{tabular}{|c|c|c|c|c|c|c|}
\hline Group & Association & Belt & Soil & Ombroclimate & $\begin{array}{l}\text { Name of the } \\
\text { habitat type }\end{array}$ & Habitat ID \\
\hline CIS & $\begin{array}{c}\text { Lavandulo stoechas-Genistetum } \\
\text { hystricis }\end{array}$ & Supram. & Acid & Subhumid & $\begin{array}{l}\text { Endemic oro } \\
\text { Mediterranean } \\
\text { heaths with gorse }\end{array}$ & 303069 \\
\hline CYT & $\begin{array}{c}\text { Genisto floridae-Cytisetum } \\
\text { scoparii, Genisto } \\
\text { hystricis-Cytisetum multiflori }\end{array}$ & Supram. & Acid & Subhumid & $\begin{array}{l}\text { Endemic oro } \\
\text { Mediterranean } \\
\text { heaths with gorse }\end{array}$ & 309016309027 \\
\hline ERI & Ericenion umbellatae & Supram. & Acid & Subhumid & $\begin{array}{l}\text { European dry } \\
\text { heaths }\end{array}$ & 303020 \\
\hline THY-PA & $\begin{array}{c}\text { Lino differentis-Salvietum } \\
\text { lavandulifoliae }\end{array}$ & Supram. & Basic & Dry & $\begin{array}{l}\text { Endemic oro } \\
\text { Mediterranean } \\
\text { heaths with gorse }\end{array}$ & 309094 \\
\hline
\end{tabular}

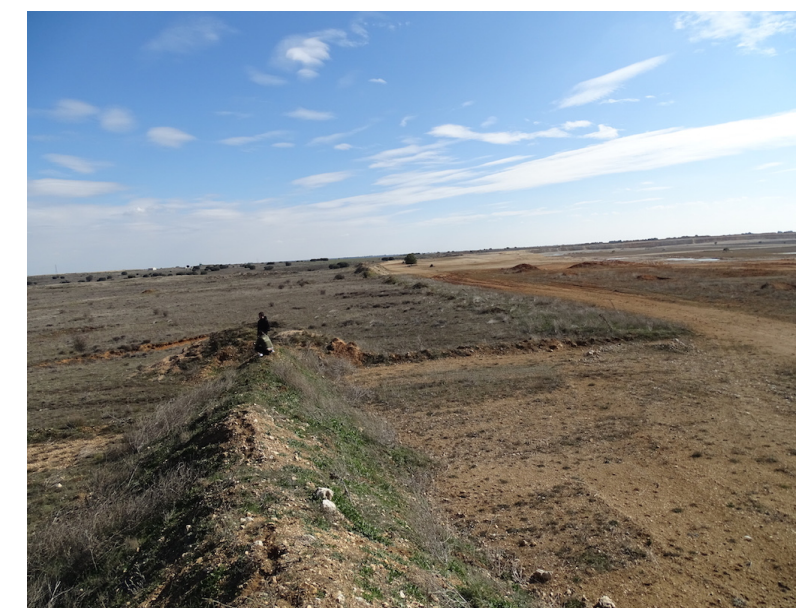

Picture 2. Large disturbance in the last habitat of Dupont's lark in El Cerrato (Palencia, Spain).

serial dwarf shrub communities of deciduous or marcescent natural potential forests (Querco-Fagetea) degraded by fires, grazing or wood-cutting. Although floristic composition within this group is similar, we can observe two different serial situations: one group dominated by Erica aragonensis (Picture 3) showing over 50\% cover)reaching a height of $80 \mathrm{~cm}$, and another with smaller proportions of Erica aragonensis Genistello tridentataeEricetum aragonensis, 303027 and abundance of Erica umbellata showing an average height of $37 \mathrm{~cm}$. This last group known as microheather, or nanobrezal in Spanish, is the typical association of Sierra de la Culebra, Halimio ocymoidis-Ericetum umbellatum, 3032D [29] [30], which replaces Quercus pyrenaica forests after fires or intense grazing. Although this last group shares no species with other communities of the lark's usual habitat, we found a similar structure to some communities of Thymus in the Iberian system and Ebro Valley. The presence of the Dupont's lark in these heathland communities is linked to most open areas.

Natural succession in heathlands is slow and usually interrupted by fires and/or grazing. Reforesting with $\mathrm{Pi}$ nus pinaster is a threat for larks and could affect the sparse areas that they inhabit in northern Zamora. Fire could act in favor of the clearing and in the interruption of the succession process effects, although it could also directly affect their much reduced populations.

In continental areas, with less rainfall, heathers are replaced with jarales belonging to the class Cisto-Lavanduletea and association Lavandulo-Genistetum hystricis, 303069 (Table 3). These jarales usually replace sclerophyllous forests (Quercetea ilicis) cleared by fire or for wood production suffering subsequent erosion of upper soil layers [30]. These communities are dominated by Cistus ladanifer, with few species more, less than 5 species per relevé, mainly Lavandula stoechas. The dense composition of these communities makes it a real mystery that larks have made them their home. Clearing of vegetation exist between the scrub and the bird has been sometimes spotted along tracks that cross the area (Picture 4, personal observation). 


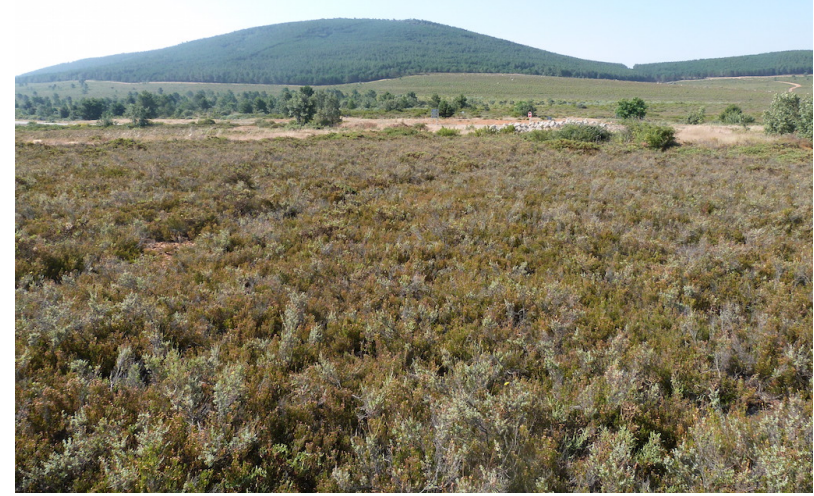

Picture 3. Heathers inhabits by Dupont's lark in Sierra de la Culebra (Spain). In the background reforested Pinus pinaster woods, a large threath for the species in these areas.

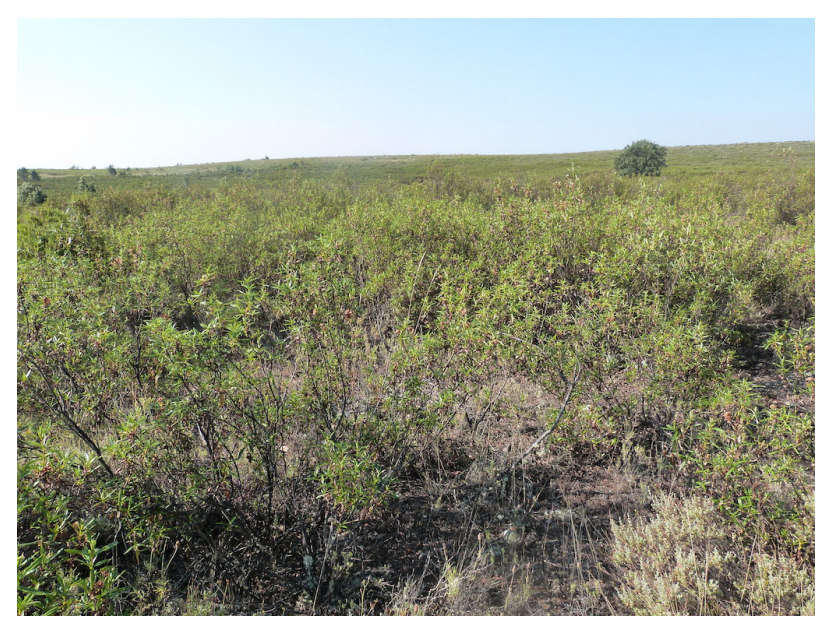

Picture 4. Cistus ladanifer communities inhabits by Dupont's lark in Zamora (Spain).

Thus, it could be that these small areas are sufficient for the survival of the species. The potential area of the Dupont's lark in these communities is small because flat areas are scarce, and many of such zones have been given over to farming or reforestation with pines (Pinus pinaster,)

Lastly, the CYT group corresponds to brushlands of the class Cytisetea scopario striatae flourishing on humic, non eroded soils as the secondary vegetation of sclerophyllous or deciduous climactic forests [23].

In these communities, larks are mainly seen to inhabit patches of Thymus mastichina and Lavandula pedunculata on sandy soils among Cytisus scoparius or Cytisus multiflorus brushlands (Table 3). These habitats belong to the association Genisto hystricis-Cytisetum multiflori, 309027, or mainly to Genisto floridae-Cytisetum scoparii, 309023. These patches show a diverse composition, averaging 19 species per relevé, resulting in a vegetation mosaic between the dense brushlands and more open areas. Usually patches are grazing lands or lands affected by fires (Picture 5), which reduces the density of communities interrupting the natural succession process. We observed these communities in the Arribes del Duero area (Picture 5, Picture 6) in a landscape mosaic composed of farmlands, dense woods and brushlands with gently sloping areas where the lark inhabits these communities. Despite the effects of fire and grazing, it is easy to note the presence of Quercus pyrenaica and Quercus ilex as colonizers of the natural succession. This could be a threat for the small patches inhabited by the lark. Once again we found reforested flat zones, a threat seen throughout all of Zamora.

Given the highly specific nature of their habitats across their distribution range, it could be that the larks of 


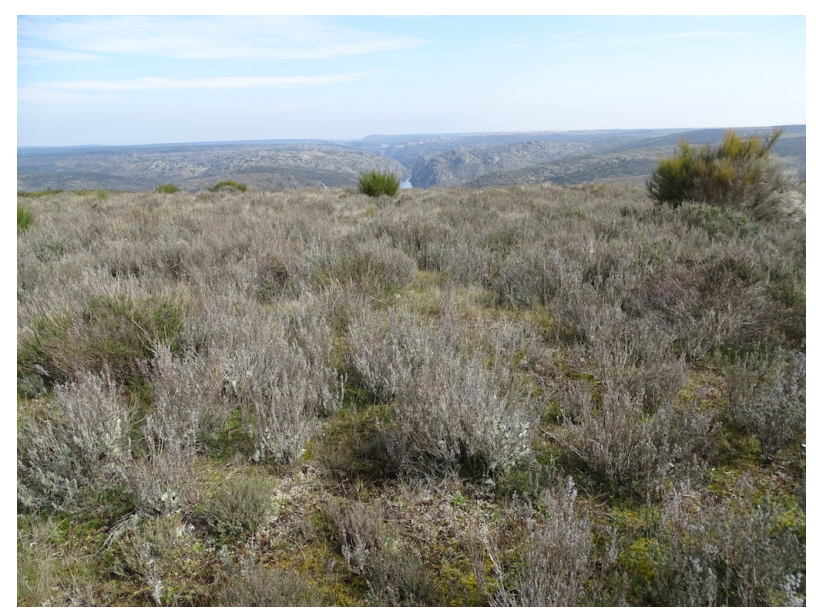

Picture 5. Thymus mastichina and Lavandula stoechas community with lark presence in the Arribes del Duero (Zamora, Spain).

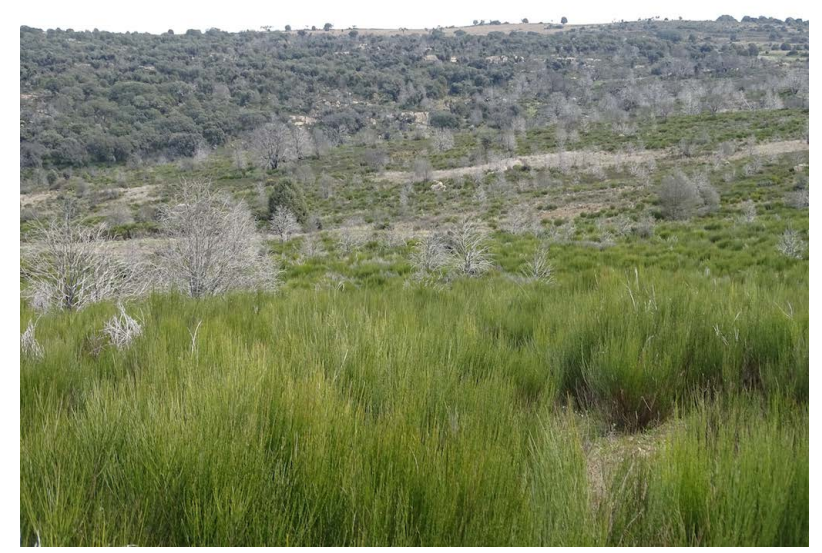

Picture 6. Patches affected by fires can stop the natural sucession and made more open areas, better habitat for Dupont's Lark. Fire affected area with lark presence in Arribes del Duero (Zamora, Spain).

Zamora are a relict population isolated from the rest, at least in terms of the peculiar habitat features. However, if we consider that the species has proven its capacity to recover following the destruction of its habitat [31], it also seems plausible that these populations were displaced towards these habitats as a consequence of marked disturbances such as fires, felling or clearing (Picture 6). Data suggest that the species may colonize disturbed areas in a dynamic movement between succession and disturbance. Recent recolonized data, like the colonization in 2015 of the Lleida location far away of the known lark locations (II Workshop of alondra ricotí, 2016) [32], and recent studies of connectivity [31], may indicate that lark spread faster than thought. Heathlands, jarales and piornales are succession plant formations such that these Dupont's lark populations are subject to episodes of extinction-colonization due to habitat loss through intense perturbation. This could indeed explain the commonly fluctuating numbers of these populations [33].

According to the source-sink theoretical model [34], the three deviant habitats observed prompt two hypotheses: they could be either source habitats in which Dupont's lark normally lives, in which case the species was not detected in other areas of similar ecological characteristics, or they could be sink habitats. If we consider that regions showing an appreciable area occupied by this lark species are found much further apart than the bird's theoretical dispersion capacity, accepting the second hypothesis sparks another question concerning the provenance of specimens that occupy such sinks. It seems that larks in this area are adapted to the episodes of extinction-colonization. It looks not likely that they could come from other populations. 
The relation found between composition-cover of relevees and the lark's density can relate density to the composition and coverage of plant species. This may indicate a path for habitat restoration measures that may apply to this species, especially in many extreme distribution areas where their population status is really worrying.

We also observe here that the areas sampled are subject to different types of threats, the most significant being the natural succession process due to the cessation of grazing, reforestation measures with Pinus pinaster and the use of flat areas for farmlands or other uses. Larks in Zamora inhabit areas in the last stages of succession of shrubs. In fact the scrubs inhabits for lark in this area are not included in the list of priority habitats of the Council Directive 92/43/EEC on the conservation of natural habitats and of wild fauna and flora, and therefore they are not protected by UE legislation (Table 3). These zones are usually small patches surrounded by more dense vegetation. Given similar habitats of acid soils exist throughout the Iberian Peninsula, the question arises as to why larks have selected these habitats of Zamora and not another similar areas. Though the issue remains unclear, the present data point to the important role played by the Dupont's lark populations of Zamora within the wider world population context and the need to further our understanding of the ecology of a species in decline whose management and conservation actions have yet to be started.

\section{Acknowledgements}

Thank to three anonymous reviewers who helped improve and clarify the paper.

\section{References}

[1] Bota, G., Morales, M.B., Mañosa, S. and Camprodon, J., Eds. (2005) Ecology and Conservation of Steppe-Land Birds. Lynx Edicions, Barcelona.

[2] Kuiper, M.W., Ottens, H.J., van Ruijven, J., Koks, B.J., de Snoo, G.R. and Berendse, F. (2015) Effects of Breeding Habitat and Field Margins on the Reproductive Performance of Skylarks (Alauda arvensis) on Intensive Farmland. Journal of Ornithology, 156, 557-568. http://dx.doi.org/10.1007/s10336-015-1159-8

[3] Kamp, J., Siderova, T.V., Salemgareev, A.R., Urazaliev, R.S., Donald, P.F. and Hölzel, N. (2012) Niche Separation of Larks (Alaudidae) and Agricultural Change on the Drylands of the Former Soviet Union. Agriculture, Ecosystems and Environment, 155, 41-49. http://dx.doi.org/10.1016/j.agee.2012.03.023

[4] Kuiper, M.W., Ottens, H.J., Cenin, L., Schaffers, A.P., van Ruijven, J., Koks, B.J., Berendse, F. and de Snoo, G.R. (2013) Field Margins as Foraging Habitat for Skylarks (Alauda arvensis) in the Breeding Season. Agriculture, Ecosystems and Environment, 170, 10-15. http://dx.doi.org/10.1016/j.agee.2013.03.001

[5] García, J.T., Suárez, F., Garza, V., Justribó, J.H., Oñate, J.J., Hervás, I., Calero, M. and García de la Morena, E.L. (2008) Assessing the Distribution, Habitat and Population Size of the Threatened Dupont's Lark Chersophilus duponti in Morocco: Lessons for Conservation. Oryx, 42, 592-599. http://dx.doi.org/10.1017/S0030605308000653

[6] Suárez, F., Ed. (2010) La alondra ricotí (Chersophilus duponti).Dirección General para la Biodiversidad. Ministerio de Medio Ambiente y Medio Rural y Marino, Madrid.

[7] Garza, V. and Traba, J. (2016) Retos para la conservación de una especie amenazada. Alondra ricotí, el fantasma del páramo. Quercus, 359, 24-33.

[8] Garza, V., Suárez, F. and Tella, J.L. (2003) Alondra de Dupont (Chersophilus duponti). In: Martí, R. and del Moral, J.C., Eds., Atlas de las Aves Reproductoras de España, Dirección General de Conservación de la Naturaleza-Sociedad Española de Ornitología, Madrid, 364-365.

[9] Nogués-Bravo, D. and Agirre, A. (2006) Patrón y modelo de distribución espacial de la alondra ricotí Chersophilus duponti durante el periodo reproductor en el LIC de Ablitas (Navarra). Ardeola, 53, 55-68.

[10] Martín-Vivaldi, M., Marín, J.M., Archilla, F., López, E. and De Manuel, L.C. (1999) Caracterización de una nueva población reproductora de Alondra de Dupont (Chersophilus duponti) (Passeriformes, Alaudidae) en el Sureste ibérico. Zool. baetica, 10, 185-192.

[11] Martín-Vivaldi, M., Garza, V., Laiolo, P., García, J.T., Tella, J.L., Suárez, F., Soler, M., Garzón, J., Marín, J.M., López, E., Pérez-Contreras, J., Archilla, F. and De Manuel, L.C. (2006) Determinación del área de distribución de la alondra de Dupont (Chersophilus duponti) en la población de El Padul (Granada). Acta Granatense, 4/5, 3-15.

[12] Peinado, M., Díaz, G., Ocaña-Peinado, F.M., Aguirre, J.L., Macías, M.A., Delgadillo, J. and Aparicio, A. (2013) Stadistical Measures of Fidelity Applied to Diagnostic Species in Plant Sociology. Modern Applied Science, 7, 106-120.

[13] Brotons, L., Mañosa, S. and Estrada, J. (2004) Modelling the Effects of Irrigation Schemes on the Distribution of 
Steppe Birds in Mediterranean Farmland. Biodiversity and Conservation, 13, 1039-1058. http://dx.doi.org/10.1023/B:BIOC.0000014468.71368.35

[14] Seoane, J., Justribó, J.H., García, F., Retamar, J., Rabadán, C. and Atienza, J.C. (2006) Habitat-Suitability Modelling to Assess the Effects of Land-Use Changes on Dupont's Lark Chersophilus duponti: A Case Study in the Layna Important Bird Area. Biological Conservation, 128, 241-252. http://dx.doi.org/10.1016/j.biocon.2005.09.032

[15] Vögeli, M., Serrano, D., Pacios, F. and Tella, J.L. (2010) The Relative Importance of Patch Habitat Quality and Landscape Attributes on a Declining Steppe-Bird Metapopulation. Biological Conservation, 143, 1057-1067. http://dx.doi.org/10.1016/j.biocon.2009.12.040

[16] García de la Morena, E.L. and Garza, V. (2015) Modelización del hábitat y análisis de conectividad de la alondra ricotí (Chersophilus duponti) para su conservación en la provincia de Zamora. In: Rivas, J.M., Rojo, M. and González, C., Eds., Libro de resúmenes del I Workshop Nacional Alondra ricotí, Estación Ornitológica de Padul, Padul, 15-20.

[17] Garza, V. and García de la Morena, E.L. (2009) La alondra ricotí (Chersophilus Duponti) en Zamora: Caracterización de la población y criterios de gestión. Dirección General de Medio Natural de Castilla y León, Valladolid.

[18] Braun-Blanquet, J. (1979) Fitosociología. Bases para el estudio de las comunidades vegetales. Blume, Barcelona.

[19] Westhoff, V. and van der Maarel, E. (1973) The Braun-Blanquet Approach. In: Whittaker, R.H., Ed., Ordination and Classification of Communities, Dr. W. Junk, Dordrecht, 617-626.

[20] Peinado, M, Aguirre, J.L., Delgadillo, J. and Macías, M.A. (2011)A Phytosociological and Phytogeographical Survey of the Coastal Vegetation of Western Northamerica. Plant Ecology, 196, 27-60. http://dx.doi.org/10.1007/s11258-007-9334-5

[21] Castroviejo, S. (coord. gen.). (1986-2015) Flora ibérica 1-8, 10-15, 17-18, 21. Real Jardín Botánico, CSIC, Madrid.

[22] Peinado, M., Arena, L. and Martínez Parras , J.M. ( 2008) El paisaje vegetal de Castilla -la Mancha. Manual de Geobotánica.

[23] Escudero Alcántara, A., et al. (2008) Guía básica para la interpretación de los hábitats de interés comunitario en Castilla y León. Junta de Castilla y León. Consejería de Medio Ambiente, Valladolid, 432 p.

[24] Rivas Martinez, S., Asensi, A., Costa, M., Fernandez-Gonzalez, F., Llorens, L., Masalles, R., Molero, J., Penas, A. and Perez De Paz, P.L. (1994) El Proyecto De Cartografía E Inventarización De Los Tipos De Hábitats De La Directiva 92/43/Cee En España. Colloques Phytosoc, 22, 611-661.

[25] Wildi, O. (2010) Data Analysis in Vegetation Ecology. Wiley-Blackwell, Hoboken.

[26] Ocaña-Peinado, F.M, Valderrama, M.J. and Bouzas, P.R. (2013) A Principal Component Regression Model to Forecast Airborne Concentration of Cupressaceae Pollen in the City of Granada (SE Spain), during 1995-2006. International Journal of Biometeorology, 57, 483-486. http://dx.doi.org/10.1007/s00484-012-0527-9

[27] Abdelmoumen, S. and Mehdadi, Z. (2015) Evaluation of Plant Biodiversity in the Steppes of White Wormwood of the Region of Saida (Western Algelia). Open Journal of Ecology, 5, 491-500. http://dx.doi.org/10.4236/oje.2015.510040

[28] Saura, S., Bodin, Ö. and Fortin, M.J. (2014) Stepping Stones Are Crucial for Species' Long-Distance Dispersal and Range Expansion through Habitat Networks. Journal of Applied Ecology, 51, 171-182. http://dx.doi.org/10.1111/1365-2664.12179

[29] Navarro, F. and Valle, F. (1983) Fitocenosis fruticosas de las comarcas Zamoranas de Tabara, Alba y Aliste. Stvdia Botanica, 2, 69-121.

[30] Rivas-Martínez, S. (1979) Brezales y jarales de Europa occidental (Revisión fitosociológica de las clases Calluno-Ulicetea y Cisto-Lavanduletea). Lazaroa, 1, 5-127.

[31] Aguirre, J.L., Larrán, J.A., Aparicio, A. and Talabante, C. (2015) Estudio de la conectividad de las poblaciones de Alondra Ricotí (Chersophilus Duponti) entorno a la comarca del señorío de Molina. Informe inédito desarrollado para la Delegación de Agricultura y Medio ambiente de Guadalajara.

[32] Pérez-Granados, C., López-Iborra, G., Serrano-Davies, E., Noguerales, V., Garza, V., Justribó, J. and Suárez, F. (2013) Short-Term Effects of a Wildfire on the Endagered Dupont's Lark Chersophilus duponti in an Arid Shrub-Steppe of Central Spain. Acta Ornithologica, 48, 201-210. http://dx.doi.org/10.3161/000164513X678856

[33] Garza, V., Suárez, F., Herranz, J., Traba, J., García de la Morena, E.L., Morales, M.B., González, R. and Castañeda, M. (2006) Home Range, Territoriality and Habitat Selection by the Dupont's Lark Chersophilus duponti during the Breeding and Postbreeding Periods. Ardeola, 52, 133-146.

[34] Runge, J.P., Runge, M.C. and Nichols, J.D. (2006) The Role of Local Populations within a Landscape Context: Defining and Classifying Sources and Sinks. American Naturalist, 167, 925-938. http://dx.doi.org/10.1086/503531 


\section{Submit or recommend next manuscript to SCIRP and we will provide best service for you:}

Accepting pre-submission inquiries through Email, Facebook, LinkedIn, Twitter, etc.

A wide selection of journals (inclusive of 9 subjects, more than 200 journals)

Providing 24-hour high-quality service

User-friendly online submission system

Fair and swift peer-review system

Efficient typesetting and proofreading procedure

Display of the result of downloads and visits, as well as the number of cited articles

Maximum dissemination of your research work

Submit your manuscript at: http://papersubmission.scirp.org/ 